\title{
Erratum to: Effects of mute swans on wetlands: a synthesis
}

\section{Guillaume Gayet • Matthieu Guillemain • \\ Pierre Defos du Rau $\cdot$ Patrick Grillas}

Published online: 12 November 2013

(C) Springer Science+Business Media Dordrecht 2013

\section{Erratum to: Hydrobiologia \\ DOI 10.1007/s10750-013-1704-5}

Due to an unfortunate turn of events, the first- and surnames of all authors were transposed in the original publication. The correct representation of the authors and their affiliations are listed above and below and should be treated as definitive by the reader.

The online version of the original article can be found under doi:10.1007/s10750-013-1704-5.

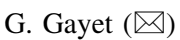

Service du Patrimoine Naturel, Muséum National, d'Histoire Naturelle, 36 rue Geoffroy Saint Hilaire, Maison Buffon, 75005 Paris, France

e-mail: gayet_guillaume@yahoo.fr

M. Guillemain · P. Defos du Rau

Office National de la Chasse et de la Faune Sauvage,

CNERA Avifaune Migratrice, La Tour du Valat,

Le Sambuc, 13200 Arles, France

P. Grillas

La Tour du Valat, Le Sambuc, 13200 Arles, France 